\title{
THE GEOGRAPHICAL SIGNIFICANCE OF FLOODS, WITH ESPECIAL REFERENCE TO GLACIAL ACTION.
}

By E. C. Andrews, B.A.

(Plates xliv.-xlv.)

\section{INTRODUCTION.}

The finding of a principle is necessary for scientific advancement : with its clear understanding one marvels that the explanation of certain natural phenomena has been concealed so long. Nevertheless, although every natural law so far discovered is excessively simple in its operation, a comprehensive, as against a microscopic, view is needful, otherwise the grand simple and central fact may be missed in the maze of attendant details. The case is analogous to that in which the names of territories or continents printed in large type across maps are missed owing to the focussing of the eye on the minute details; similarly, novices experience difficulty in grasping the principle of the steam engine when confronted, for the first time, with a near view of the subsidiary parts. Apparently the case of stream-development is no exception. The belief that streams have, in the majority of instances, carved their containing valleys; that sea-currents have moulded the shoreline curves; and that glaciers have, to some extent at least, modified the preglacial valley-contours, is very widely entertained; nevertheless the significance between extreme flood and drought stages appears to have been strangely overlooked. The great difference in the work performed during these extreme phases of stream-action may have been frequently admitted, but the application of the principle has not been seriously considered. Thus, are we to consider the work of the normal stream or that of the mighty flood as our unit in estimat64 
ing stream corrasive effects? Whichever is taken, the problem resolves itself into a summation of excessively numerous and relatively small activities. Is the valley the summation mainly of many thousand flood-thrusts; or is it rather the "integration of an infinity" of normal and drought stream effects?

If now it can be shown that floods of great strength produce characteristic and important forms in valley channels; and furthermore that these characteristic and dominant forms remain virtually unaltered until the return of an equally great, or still greater, flood, we should obviously feel inclined to assign by far the more important corrasive effects to flood-action.

Moreover, if a study of very small flood-channels, such as roadside storm-gutters and brooklets; of larger examples such as those of rivers and shorelines; and of mighty channels also such as Alpine and Sierran cañons, channels undoubtedly subject to former intense glacial action-if a study of these, we say, should reveal, in each type, the presence of peculiar and prominent contours all of similar shapes; and not only so but a similarity of situation in each case for such contours, the difference in size being the only essential point of distinction; and furthermore the size being in direct proportion to the size of the various floods-then indeed we might reasonably feel much more strongly supported in our contention. We would be prepared, of course, to admit the corrasive properties of streams in their normal or even in their drought stages; nevertheless, since the flood-contours are only seriously modified, or possibly effaced, by other deluges, land-reduction would appear to be virtually accomplished by gread flood-corrasion.*

Thus if this simple principle be grasped, it will at once be seen how geographical methods will be revolutionised. For seeing that shorelines, stream-developed valleys and fiord-contours are the work of comparatively Titanic forces, it would be useless for one to study the methods of the harmless drought-stricken

* Similarly for land-reduction by wind-action, the work of the great windstorm should altogether overshadow the effects of the intergale and the zephyr stages. 
streams in order to appreciate the real shock of attack by which the land-contours had been carved. He who would see the true state of affairs must watch the Titan delivering his heaviest blow. Not that the succeeding pigmy-streams are incapable of continuing the work started by the giant, but merely that, while yet they are occupied in obliterating the Titan's marks, he again returns and carries on his former work of reduction.

The clear conception of the fact that shorelines, valley-floors, and fiord-contours result from the action of successive mighty floods, would put to rest many disputed points in glaciation and peneplanation; for it would at once be observed that drought streams slumber peacefully among the wreckage produced by the floods. So enormous were the weapons with which the giant streams armed themselves, and so flat were the grades they produced, that all the energies of normal streams or glaciers are utilised in merely filling up the holes resulting from such Titanic attack, or in forming lakes to surmount the masses of débris dropped here and there in the bed of the stream, upon the retreat of the great flood.

So simple was the principle that many workers appear, tacitly, to have admitted it; nevertheless they would not perceive its main significance. To Dr. G. K. Gilbert (17, a pp.89-90) belongs* the honour of having first, in 1883, clearly enunciated the principle as it applies to ordinary streams and coastlines. Yet even that acute and philosophic geologist hesitated to apply his own $\dagger$ far-reaching discovery to glacial studies.(17)

The present paper is an attempt to throw further light on Gilbert's principle by a comparison of observed small effects, such as one sees in storm-gutters, with the grand contours obtaining along large streams and glacial channels.

* Gilbert, G. K. - Quoted at length later (p.800). The idea had occurred independently to the present writer in 1905. See Andrews, E. C. (postea). Dr. Gilbert's paper was not read by the writer until 1907.

$\uparrow$ Dr. Gilbert in a letter to the writer (August, 1907) states that this idea came independently and contemporaneously to both J. W. Powell and himself. 


\section{Causes leading to present statement.}

The writer was led to apply Gilbert's principle as the result of a short visit to the Lakes and Sounds of South-Western New Zealand in 1902-1903. During that trip a number of topographic forms, totally unlike those of non-glaciated Australia, had been observed. For a time no solution could be found to the problem. At this juncture a glacial note $(9, a)$ and a letter were received from Prof. W. M. Davis. So simplystated were these notes that no doubt existed in the writer's mind as to "glaciation of preglacial valley contours" being the key to the problem. At a later date the writer $(1, a)$ was led to announce the "Flood Hypothesis" to account for the peculiar forms exhibited by the sounds and associated lakes and cañons. The stagnation of present-day glaciers in Alaskan fiords; the overriding of glacial débris by the same ice-masses, and the lack of corrasive power exhibited by Alpine and other glaciers, all seemed explicable on this assumption of former ice-flood action.

Stream-studies were then entered upon in some little detail. Along gutters, floods were observed to excavate holes almost identical in shape with those of typical cirques, sound and lakebasins, as also to glacial cañons. Pronounced stagnation during drought or interstorm (flood) periods was noted. From these attention was directed to incipient cañon-contours, then to brooklets, brooks and rivers. In all, similar and similarly situated forms were observed. In every instance basins were seen to have been excavated at points of marked convergence; at points of weakness; and also other points of heavy thrust in the large or small cañons. The valley-basins were observed to possess reversed grades downstream: in short, they were miniatures of the fiord-and lake-basins existing in regions of recent intense glacial action.

One was thus led, step by step, to reason from flood-effects in small channels such as roadside gutters, incipient cañons and brooklets, to those in basins and spurless cañons of intensely glaciated regions. In a word, knowing that certain gigantic and remarkable "facts of form"-to wit, cirques, fiord-and associated 
lake-basins, spurless cañon-walls, and hanging valleys-always and only obtained in glacial regions; knowing also that these contours are duplicated in miniature along river flood-channels (allowance being always made for the stage of development attained); knowing moreover that these forms are again duplicated, but still less in size, along roadside gutter flood-channels, these last-mentioned forms being, by direct observation, undoubtedly the product of floods; and, finally, knowing that ice- and water-streams are somewhat analogous,(31) in general aspect; might not all these contours be interpreted as the early attempts of floods, varying in magnitude, to cause approximation of their channel bases to sea-level?

An analogy drawn from botanical studies may not be irrelevant in this connection. No one has seen any individual forest monarch in all its successive stages of sprouting, maturity, old age, and advanced senile decay, yet, even were the testimony of history outside his own experience withheld, no observer could doubt that each and every forest king possessed such stages of development; in the first place because the forest abounds with individuals representing all stages of growth and decay, and secondly, because each year one sees the birth, growth, decay and death of plant "annuals," these varying from the forest kings only in points of size and longevity. The observer simply grasps clearly the life-stages of the "annual," and then, from these small forms, infers the life-history of the greater.

To the observant, it is thus also with the small roadside gutter-basins--the product of severe storms-the Amazonian channel-basins, and the fiord-basins, the latter expressing the summation of huge flood-thrusts.

The writer's best thanks are due to H. Hoggan, Esq., for the drawing illustrating the contours produced in a creek-base during a flood at Bouralong in New England, N. S. Wales.

Some recent Advances in Stream and Glacial Studies.

At this stage it may be advisable to note certain recent advances in stream and glacial studies, all throwing light upon 
the subject under discussion. Between the periods 1874 and 1883, the scientific epics of Dutton,(10) Gilbert, $(17, a, b)$ and Pòwell(23) were produced. So clear is Gilbert's statement concerning flood-action that one marvels at the persistence of the glacial controversy.

For the benefit of all, Gilbert's(17,a,pp.89-90) grand announcement is here reproduced.

"The explanation of these inequalities depends in part on a principle of wide application, which is on the one hand so important and on the other so frequently ignored that a paragraph may properly be devoted to it, by way of digression. There are numerous geologic processes in which quantitative variations of a causative factor work immensely greater quantitative variations of the effect. It is somewhat as though the effect was proportioned to an algebraic power of the cause, but the relation is never so simple . . . . and it gives to the exceptional flood a power greatly in excess of the normal or annual flood. Not only is it true that the work accomplished in a few days is greater than all that is accomplished during the remainder of the year, but it may even be true that the effect of the maximum flood of the decade or generation or century surpasses the combined effects of all minor floods. It follows that the dimensions of the channel are established by the great flood and adjusted to its needs.

"In littoral transportation the great storm bears the same relation to the minor storm and to the fair-weather breeze. The waves created by the great storm not only lift more detritus from each unit of the littoral zone, but they act upon a broader zone, and they are competent to move larger masses. The currents which accompany them are correspondingly rapid, and carry forward the augmented shore-drift at an accelerated rate. It follows that the habit of the shore, including not only the maximum height of the beach line and the height of its profile, but the dimensions of the wave-cut terrace and of various other wave-products presently to he described, is determined by and adjusted to the great storm. 
"It should be said by way of qualification that the low-tide stream and the breeze-lifted wave have a definite though subordinate influence on the topographic configuration. After the great flood has passed by, the shrunken stream works over the finer débris . . . the smaller waves of fair weather construct a miniature beach profile adapted to their size. . . . Thus, as early perceived by De la Bêche* and Beaumont, $\uparrow$ it is only for a short time immediately after the passage of the great storm that the beach profile is a simple curve; it comes afterwards to be interrupted by a series of superposed ridges produced by storms of different magnitude."

McGee's paper of $1883(21, a)$ is a remarkable statement. Attention is drawn therein to typical glacial profiles, and a great case for glaciation is here unmistakably stated.

Russell in 1889, $(25, a)$ Cushing $(6, a)$ in 1891, and Russell again in $1892(25, b)$ experienced difficulties in accepting the glacial explanation for certain cañon-contours. Especially were these difficulties experienced in attempting explanations of the moraineoverriding habits, and general stagnation of the Muir and other glaciers.

McGee in $1894,(21, b)$ when considering the mechanics of glaciation, Culver in $1895(5, a)$ and Reid in $1896(24, a)$ all record apparently anomalous phenomena, which, however, apparently admit readily of explanation on the assumption of former ice-floods.

The 'Great Ice Age,' by Dr. J. Geikie,(16) furnishes a grand summary of glacial knowledge up till 1898. Incorporated with this volume is a concise statement by Chamberlin of glaciation in North America.

The articles by Chamberlin $(3, a, b, c)$ and Salisbury(26) throw much light on glacial mechanics.

In the illustrations accompanying Chamberlin's Reports, one sees repeated evidence of the shearing and overthrusting of ice-

* Manual of Geology. Philadelphia, 1832, p.72.

† Leçons, p.226 and pl.iv. 
layers in glaciers. This, by some observers, has been adduced as evidence of the incompetence of ice-erosion. Yet this is what one would expect from a study of ordinary streams. Every river has a down-stream motion; nevertheless, at almost every point, eddies are set up by reason of channel obstaeles; and these eddies give rise to breaking and shearing of water-masses. Compare also the breaking of waves, the wave of translation, the undertow, the leaping of torrent flood-waters, and the violent dashing of the same around rocks and other channel obstructions. Notwithstanding this evidence of waste force, no engineer of repute would believe that such eddying and overthrusting of water-masses argued corrasive incompetence for that particular stream. On the contrary, these shearings reveal intense action which finds partial relief upwards by reflection. Dr. W. G. Woolnough, of Sydney University, in conversation with the writer, mentioned the action of a great flood witnessed by him in Fiji. So great was the rush of storm-water that, not only water-masses, but large stones were thrown high above the stream-surface by the tremendous force of the eddying current.

Gannett's "Lake Chelan "(13) apparently marks the commencement of a new era in glacial work. Fresh light is thrown on the problem by his descriptions and discussion.

Penck again, in 1899 , as quoted by Davis, $(9, a, \mathrm{p} .319)$ stated the case for vigorous glacial erosion in the Alps.

Both Gannett and Penck have drawn attention to certain similarities existing between glacial and ordinary stream-channels.

It was, however, a comprehensive paper by Davis, in $1900,(3, a)$ which caused the Writer to become a "glacialist." As a result of meditation on the excessive simplicity of Davis's statement, the idea was entertained that the existence of a former great ice-flood would throw light on such apparent anomalies as presentday glacial stagnation, moraine-overriding by ice-masses, the peculiar appearance of drumlins, and other points.

Gilbert's contribution, in $1899,(17, a)$ marks a decided progressive move. To him we are indebted for the term "Hanging 
Valleys," as also for an expinnation of these peculiar forms. Russell and McGee had, still earlier, called attention to these contours. McGee had also supplied as explanation.

Matthes's report of $1899,(20)$ as also his topographic maps of Yosemite, are another valuable addition to our nnowledge of Sierran glaciation, especially in connection with cirque-formation.

Johnson, in 1904,(19) summarised the main topographic points of the Yosemite. As a result of his excellent observations he he was led to announce a method of cirque-formation by forces acting along lines "curving sympathetically" with those of bergschrunds.

Tarr in various papers $(27, a, b)$ called attention to the marvellous contours of the Finger Lake and other regions. His latest paper(12) contains very clear statements of the efficiency of ice as a rock-corrader.

Westgate, in $1905,(30)$ quotes a concrete case in which a later ice-visitation had, in the main, succeeded merely in aggrading the excavations made during an earlier glacial period. He, however, does not generalise from the observation.

\section{Thesis.}

The great flood is the main corrasive factor in peneplanation. A "flood" may be defined as that stream-volume which is competent not only to utilise the channel-base as a bridge for the transportation of the heaviest stream-material, but has enough residual energy to cut vertically into the live rock of its channelbase. All other stream-volumes are comparatively negligible as regards corrasion. Roadside gutters, brooklet, brook and river valleys, shorelines and glacial cañons have dominant shapes all similar and similarly situated.

Present-day fiord (and some cañon) glaciers should be inactive in their channels, with overriding of moraines.

On the assumption of a recent ice age, many contours may thus be predicted for glacial regions. 


\section{Types of Flood-Channel Contours.}

For the sake of simplicity the order observed in the following channel-contour descriptions will be from smaller to larger.

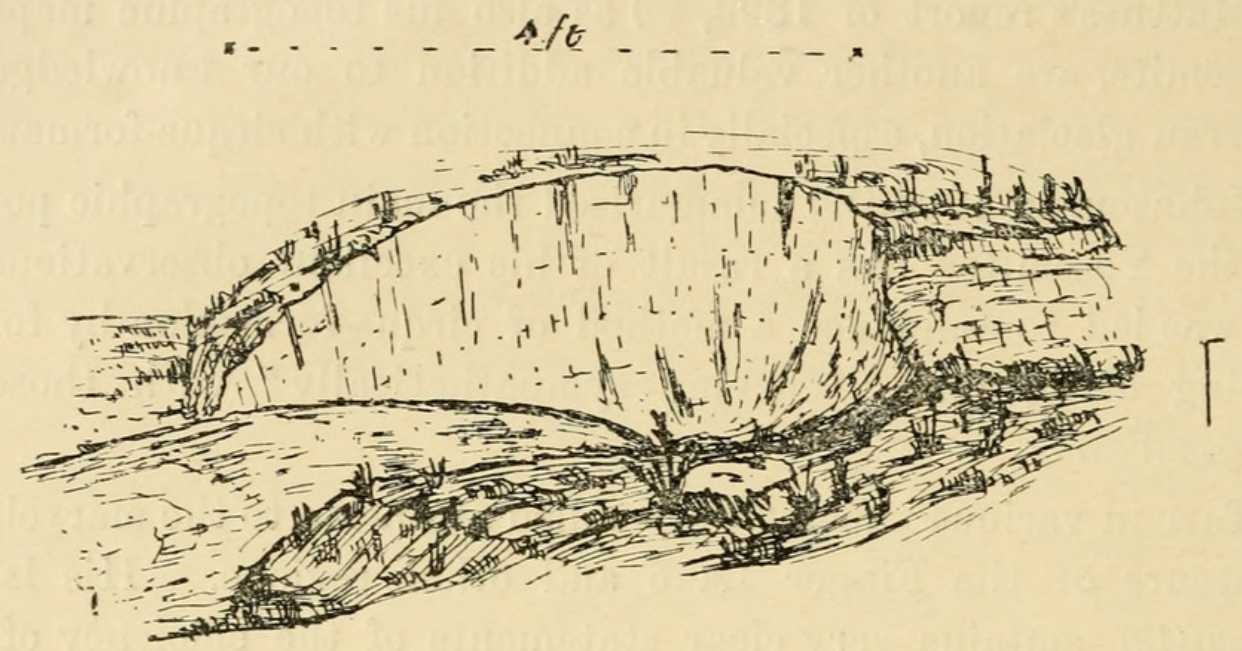

Fig.1.-Basin formed in hard clay during heavy storm; Emmaville, New England. Note the aggradation by decrease of gravitative water-thrust.

1. Roadside gutters. - It must be understood at the outset that the contours here described refer to country tracks which have
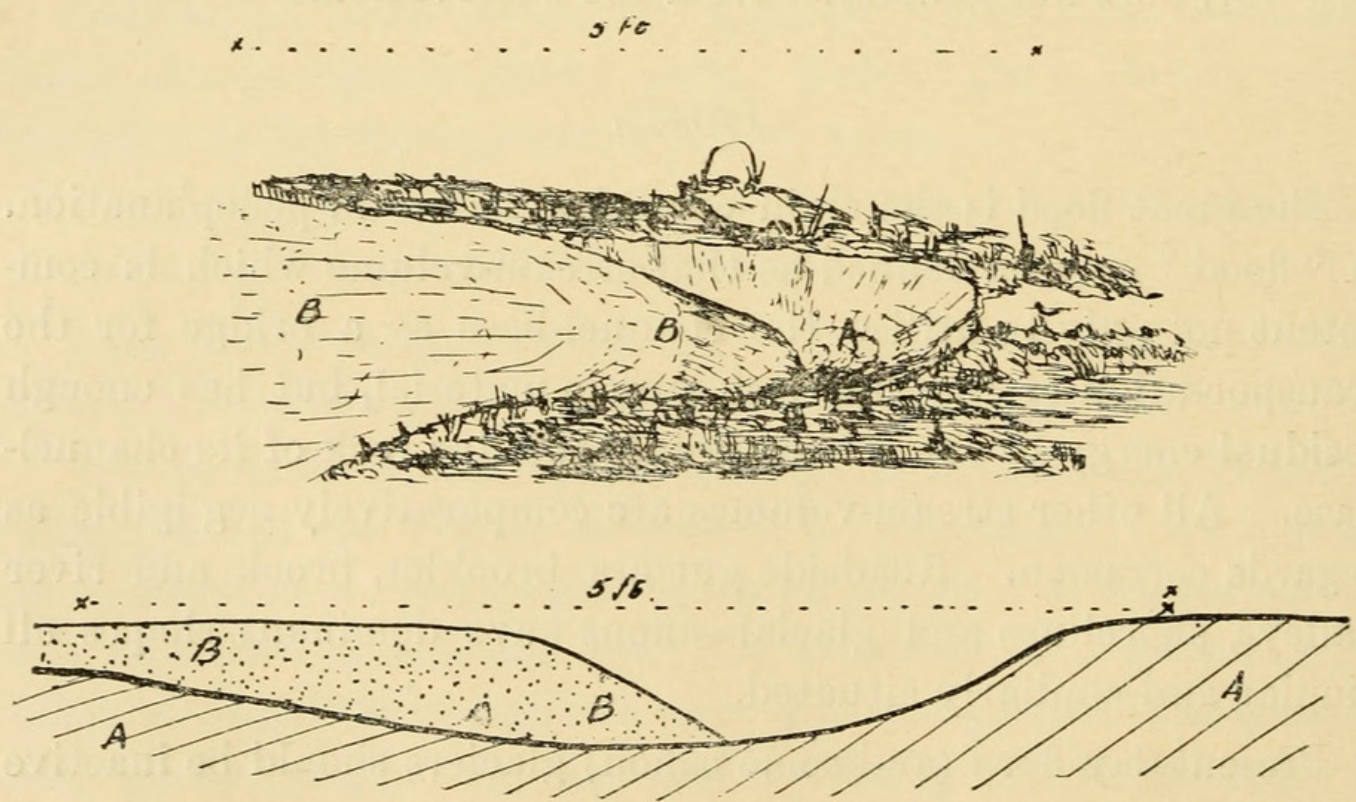

Fig. 2. - Small basin formed in hard clay at Tenterfield (New England) during heavy storm. Note the decrease of storm-water as shown by partial aggradation of basin. This figure throws much light on cirque and fiordbasin formations, also on drumlin and moraine distribution. 
fallen into disrepair. The peculiar contours of these gutters are well known to be developed during severe rainstorms. The forms depend upon the material acted upon; this may be homogeneous and coherent; it may be soft basally and have a hard capping; or it may be soft above and hard below. The homogeneous and coherent structures alone will be here considered, as the reader may easily reason out the contours for the nonhomogeneous structures from a knowledge of the forms produced in the simplest case. A disused foot, bridle or wheel-track in tenacious clay or rotten rock very frequently constitutes the

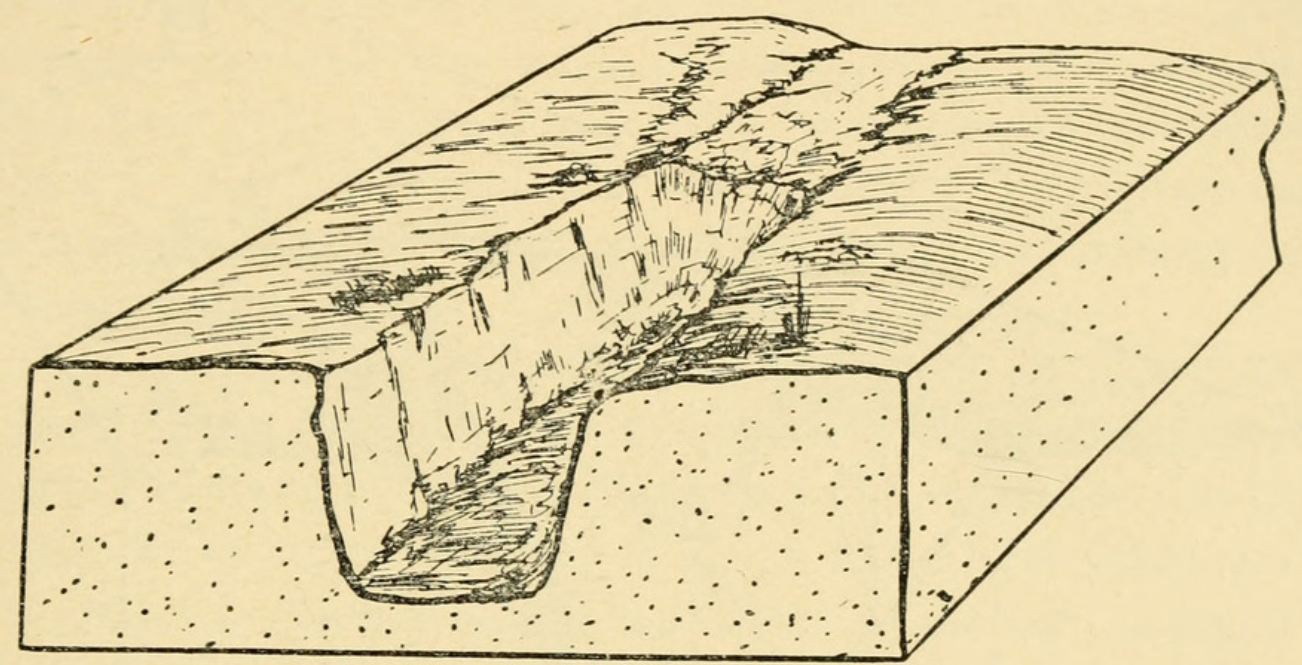

Fig.3.-Trench with amphitheatrical (or cirque-like) head formed in hard clay during heavy thunderstorm. The trench originated in a basin, as shown in figs. 1 and 2 ; and the recession of the basin-head caused the long gutter with its straight sides and broad base. The figure illustrates a possible origin of fiord-basins.

original valley. These tracks may have been but a few inches deep and less than a foot in width. In regions subject to violent thunderstorms the valley, after several years, is probably from one to two feet in depth and has, comparatively, a very wide floor, straight or very steep sides, spurless walls, a fairly uniform grade broken every here and there by amphitheatrically-headed trenches, the amphitheatre bases existing in the form of basins, deepest near their upstream ends. Stream débris is commonly plentiful near the downstream end of the basins. Again, basins 
are commonly located at rut-convergencies and immediately below local barriers or hardnesses such as rocks and tree-roots. Portions only of these gutters may consist of trenches such as those just described, nevertheless, where they occur, the smaller side-streams near the amphitheatrical heads are "hung up " over the main rut.

2 Incipient Cañon-Contours.-These interesting geographical features represent the more advanced stages of road-gutter, or similar valley, making. Very frequently they occur in decom-

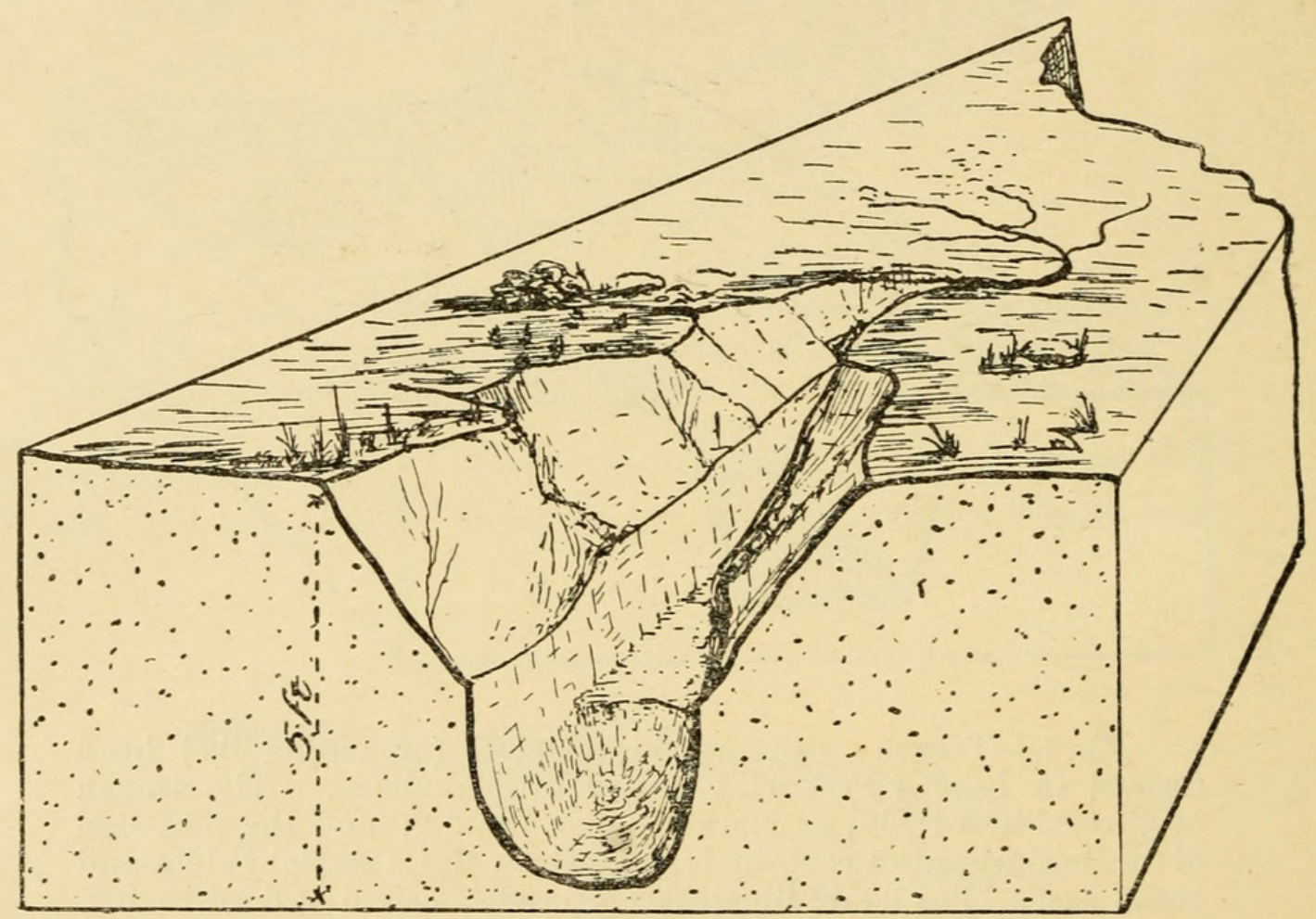

Fig.4.-Incipient cañon formed by flood-waters at Uralla (New England). Note the double slope in the cañon. The lower valley showing basin, spurless walls, and $U$-shape in section marks the work of a very heavy storm. The upper portion of cañon shows ordinary spur-development. The lower contour shows a remarkable resemblance to glacial forms.

posed rock-masses, and they may, in a few decades, attain depths as great as 50 feet. They also afford striking examples of V-shaped valleys possessing well-marked overlapping spurs. Their origin, in New England, can be usually traced to the 
action of floods along disused wagon tracks, or "tailraces" in alluvial mining. The largest examples known to the writer in New England are 50 feet deep, and the greatest age known is 50 years. But, whereas the ordinary road-gutter is wholly occupied by storm-waters, the bases only of the young cañons under consideration are so occupied. If attention be confined to the lowest portions only of these gulches there will be found basins, U-shaped sections, and stretches of channel-base rectilinearly disposed, all similar to those found along the gutters. This lower portion is that which is occupied by the heaviest storm-waters. Above these flood-channels one finds V-shaped valley-sections and the other characteristics of valley-slopes which have been determined mainly by weathering and stream trickles. It will be found also that hanging valleys occur along these lower portions in positions similarly situated to those along ordinary road-gutters.

The accompanying sketch illustrates contours of a tiny cañon at Uralla, New England. The observations here recorded deserve careful consideration, inasmuch as they throw considerable light on the characteristic contours of fiords and Alpine lake-regions.

3. Brook and river-channel contours. - These will be found to represent features very similar to those of incipient cañons. One or two distinctions may be drawn, however, between the types, whereas the flood-channel of the incipient cañon occupies a considerable fraction of the whole valley, the flood-channels of ordinary brooks and rivers generally occupy but an insignificant portion of their containing valleys. Again, the incipient cañon is but the product of a few years' stream-corrasion, and as such its features stand out plainly; whereas the ordinary streamdeveloped valley, representing, possibly, the action of streams during millions of years, has its contours softened and partially concealed beneath rock-waste and vegetation. Yet the frequent

* A "tailrace," in Australian alluvial mining, signifies a small channel situated below ground-sluicing operations, and employed as a "getaway" for the earthy material associated with the valuable minerals. 
basins and broadly $U$-shaped contours are, in each case, found both similarly shaped and similarly situated.

Chamberlin and Salisbury (4,i.p.79) mention the occurrence of a basin at Fort Jackson, excavated by the Mississippi, 250 feet below baselevel. The authors do not state the occasion, or occasions, necessitating such powerful gravitative thrusts; whether obstructions, convergence of tributaries, or formation of small basin at convergence and later enlargement linearly by headward growth.

In ordinary stream-valleys also, freedom from débris often characterises channel-narrows, while aggradation marks channeldivergences.

In the discussion it will be seen how applicable all this is to the case of glaciation, whether considered as Alpine or continental glaciation.

4. Glacial valley-contours.-The magnificent descriptions of Davis, Gannett, Gilbert, Johnson, McGee, Penck and others, have made typical glacial valley-contours familiar to all readers.

In New Zealand one finds equally characteristic contours in Hall's Arm, Crooked Arm, Lake Te Anau, Milford Sound, and the Hollyford Valley.

The cañon floor is frequently terraced $(19,22 a)$, the terraces being subhorizontal and rising from one to the other by means of amphitheatres or cirque-like forms. For considerable distances spurless walls characterise the cañons, while magnificent cirques commonly form valley-heads. Small rock-basins lie at the feet of the cirques, while frequently low cols, U-shaped in section, lead to similar valleys across the divides.

The cañons of south-western New Zealand end in large rockbasins, sometimes 40 to 50 miles in length, their bases being as much as 2,000 feet below local or main baselevel. Moreover, these basins show reversed grades lower downstream, while tributary streams are well hung up above the main lake or sound floors. The following sketches, as also Plates xliv. and xlv., illustrate well these contours of formerly glaciated regions. 
Such deeper basins occur at or near marked cañon-convergences, within walls of exceptional height and strength. Here, also, occur the finest hanging valley types. Very little morainic material is to be found in these steep cañons.

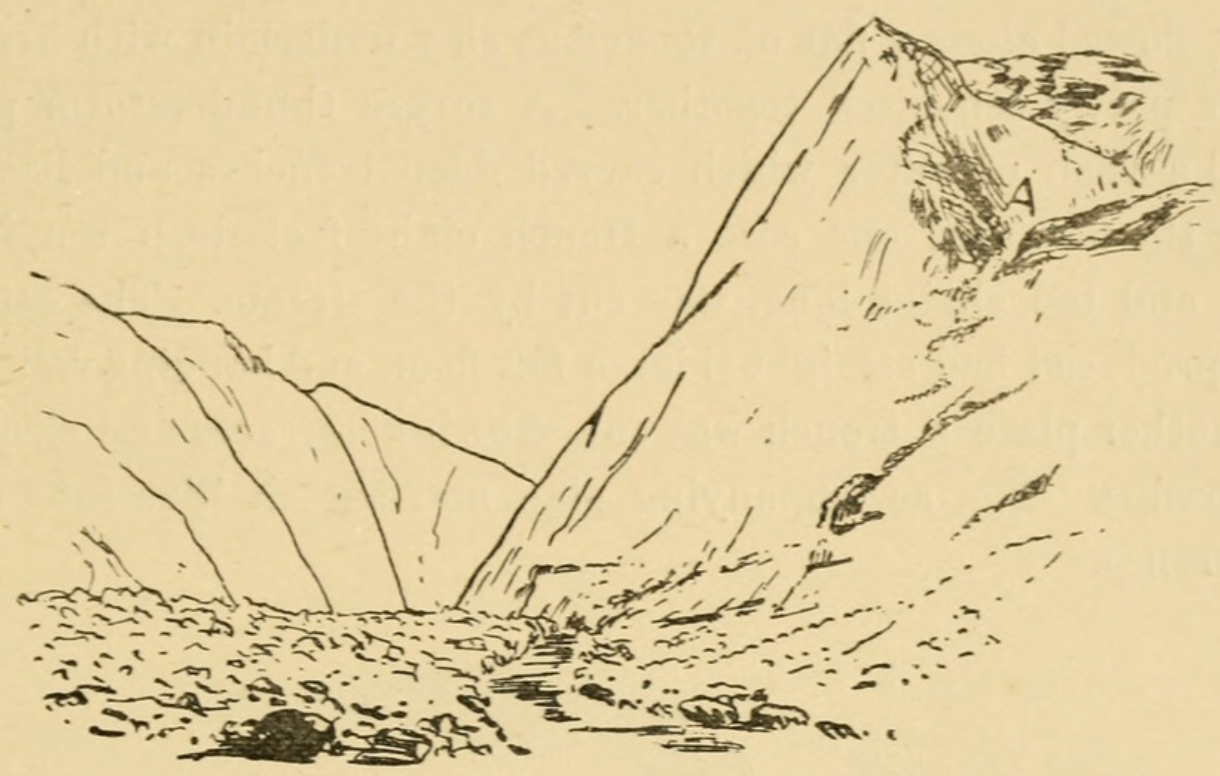

Fig.5.-The Sentinel, Clinton Valley, N.Z., 3000 (?) feet above valley. A truncated spur, the truncation causing the hanging valley at $A$.

If, now, these forms be compared with those of ordinary stream-valleys, it will be seen that the cirques, lake- and soundbasins, spurless walls and flattish floors are all Brobdingnagian equivalents of the basins and narrows in the flood-channels of the various stream-valley types. In the one case the flood-channel occupies but a fraction of the valley, while in the other the glacier, or ice-flood, occupied almost the whole of the cañon, This point, I think, has been especially emphasised by Prof. W. M. Davis (9a,p.293),

It is, however, when comparing glacial cañons with the gutters produced by floods along disused roads, that the great resemblance to glaciated cañons is noticeable. In both cases the flood occupied either the whole or the greater portion of its, valley. 
Examples of Flood-action as observed by the Author.

The forms to be now described occur in the northern and eastern portion of New South Wales.

(a) Boural ong. - Here a creek, with a run of about two miles, flowed along a flat of tenacious clay underlain with heavy stones partly cemented together. A severe thunderstorm produced a rush of water which carved deep trenches and basins along the flat. In one case a trench eight feet deep, ten feet wide, and ten chains long, was cut by the stream. The cañon thus produced had straight sides, a flat floor, and hanging valleys. In another place a trench was cut showing terraces and cirquelike basins. The accompanying plan and sketch illustrate the occurrence.

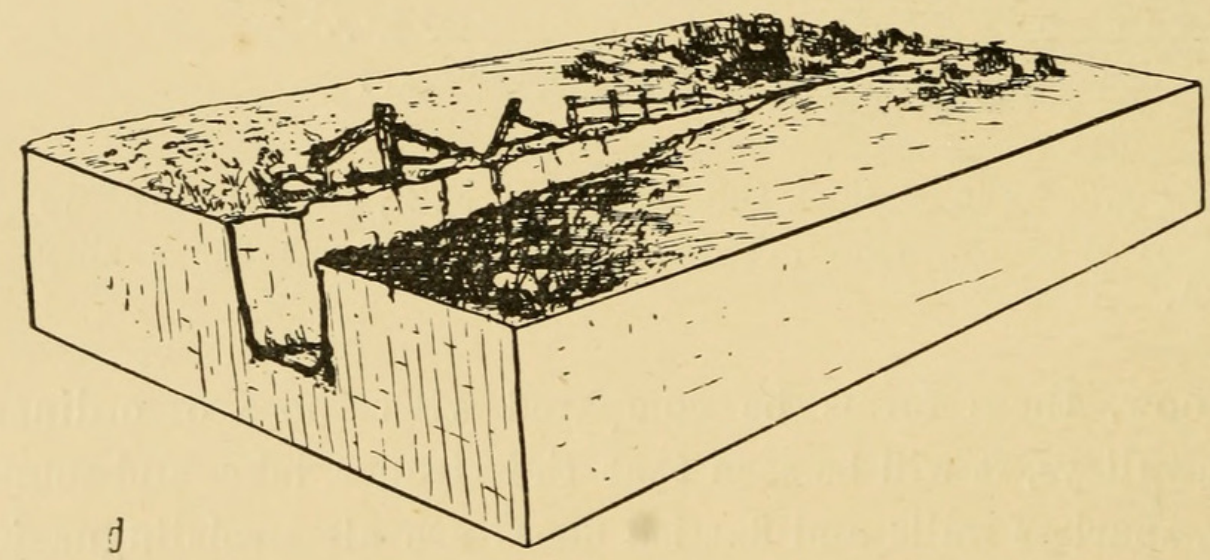

Fig.6. - Trench formed at Bouralong (New England) during severe storm. Length of trench, 10 chains (220 yards); width and depth, 8 feet. Note the straight walls and the broad base. The trench was formed by recession of a waterfall originating in a marked acceleration of velocity caused by a channel-obstacle situated on a decline.

These long trenches were not excavated by a single convergent thrust, but commenced rather as small amphitheatres due to stream-convergence, or gravitative thrusts, determined by obstructions. The waterfall thus started quickly worked its 
way backwards, leaving a deep trench and basins in its wake. Especially does this observation throw light on Alpine lake and sound basin-formation by ice-floods.

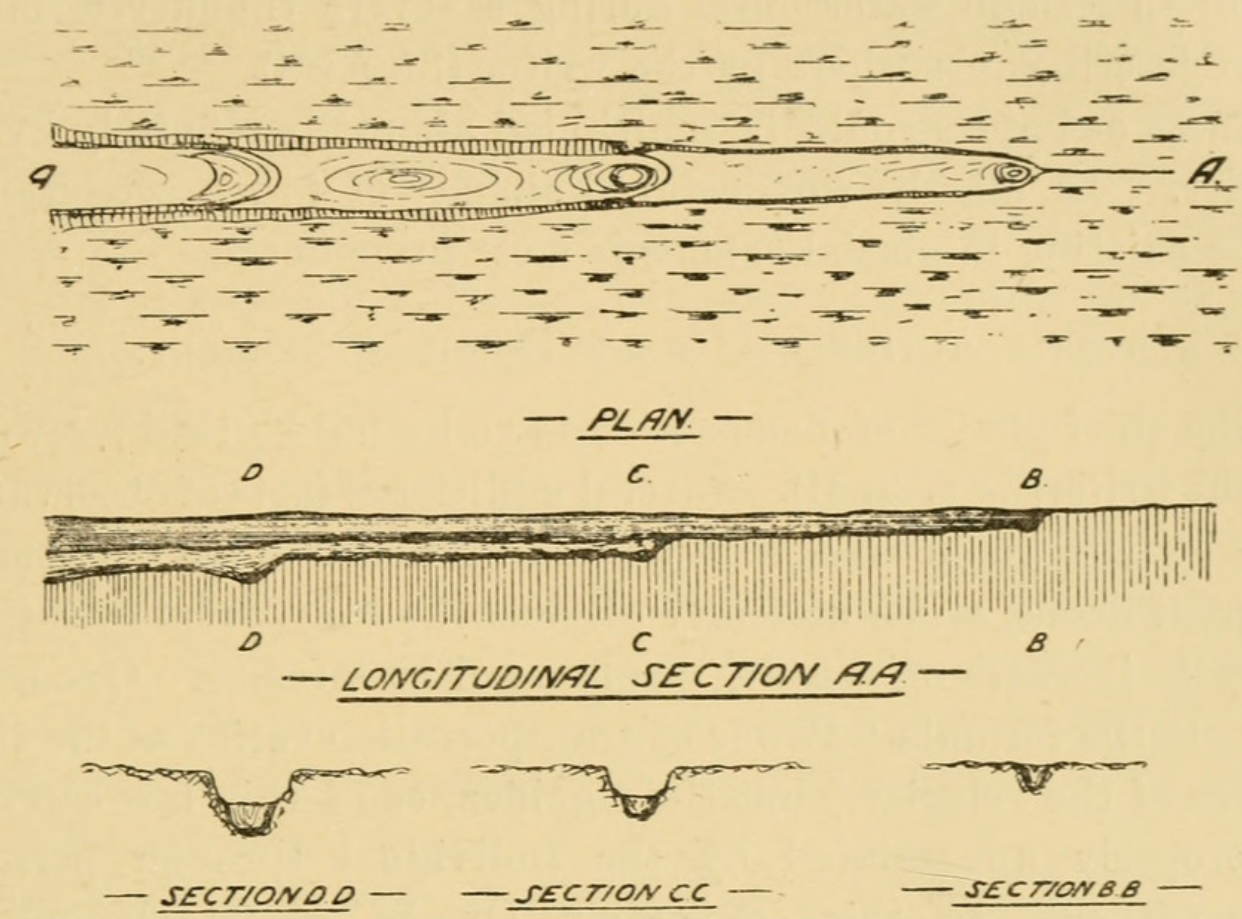

Fig.7. - Plan and section of a peculiar series of basins formed in hard clay, during a severe storm at Bouralong. The figure throws considerable light on the formation of cirques, lake-basins and eañon-contours. Drawing by H. Hoggan.

(b) M uddy Creek, Sydney.-This watercourse has a run of some two miles above the basin-form now to be described. During the "Dandenong Storm" in 1876, the creek carved out an amphitheatrically-headed basin some 20 feet below the local baselevel. The basin remained for some 20 years, when successive flood-action had succeeded in aggrading it.

(c) Hillg rove.-During the severe flood which visited New England in 1893, an angular block of granite, some 40 tons in weight, lying in the bed of a small watercourse, was carried two chains downstream by a heavy rush of water. Hosts of boulders, several hundreds of pounds in weight individually, were carried for great distances downstream. Succeeding floods have been 
able only to partly override these boulder-heaps, without moving them.

(d) Schofield's Creek.-The marvellous work effected along this small watercourse during a severe thunderstorm has been described elsewhere by the writer $(1, b$, p.504).

These examples could be multiplied almost indefinitely by the reader. In all, the wonderful similarity of forms produced to those existing in glacial cañons is most pronounced.

\section{The Action of Great Floods generally.}

The chief phases of flood-action have been described elsewhere by the writer(1,a,pp.34-41). Several additional facts of observation may be here noted, since to those unaccustomed to the phenomena of great floods, much difficulty attends the conception of ratio of work to increase of velocity as observed by streams. One easily repeats the formula "Power of transportation varies as the sixth power of the velocity," but the significance of this law can only be properly appreciated by the individual through personal observation. In this connection Dr. W. G. Woolnough, of Sydney University, described to the writer a most severe rainstorm in Fiji during which boulders were swept along a creek bed with such force as to leap high out of the water. In such cases, also, whole masses of water are sheared and driven high above the flood-level. Again, the placid water above the Niagara or Zambesi Falls is the same water which, a little later, rushes in its mad career below the falls. The former may be considered the normal stream, the latter a furious flood, and this simply by reason of greatly increased velocity. In the ordinary stream it is the volume of the flood which produces the increased speed, whereas at Niagara and the Zambesi it is the steepened grade which accelerates the velocity.

Again, during floods torrent-narrows are also scoured, and the débris swept thence into valley-divergences. Shearing and eddying of water-masses, as also the scouring of stream-narrows, find their analogies in glacial action. As such shearing and eddying are at a maximum during the period of greatest efficiency 
of a river-flood, we may extend the same reasoning to the iceflood; and thus conclude that great ice-shearing and cañonscouring should mark the period of greatest glacial intensity.

On the other hand, the great flood is after all but a study in limitations, for at its very height it aggrades as well as corrades. It cuts vigorously on one side and forms deposits opposite the cutting curve. So does the glacier. But in the latter case the flood was not confined to the cañon base. At times the whole lower cañon might form its cutting side, and the aggrading portion might have to be sought high up on the cañon sides or in a marked valley-divergence.

Recession of high-water mark.-With the least recession of the flood comes the dropping out of the heaviest boulders, that is, those which for their moving taxed the utmost strength of the giant. The subsiding water now no longer possesses the energy - gravitative thrust-- to use the reversed grades as bridges for transportation of stream débris : forthwith it commences to build out deltas into the depressions.

Action of smaller floods. - The smaller flood works over the material left by the great flood, and provides therein for itself a channel similarly shaped to that of the maximum flood. This follows immediately either from direct observation or from a study of the mechanics of flowing water. It cuts basins and other channel-contours now not in rock but in storm-débris, as its strength is incompetent to deliver blows equally telling with those of its predecessor. The largest flood-boulders are not shifted, but merely overriden wholly or in part.

It cannot, however, too frequently be stated that smaller floods are quite capable of accomplishing peneplanation themselves, but the great flood is of such common occurrence that the forces of weathering have not time enough-during interflood periods-in which to promote rock-decay whereby the smaller flood might accomplish rock-basining.

5. Shoreline forms. - The recent "incisive" account of shorelines by Gulliver,(18) as also the classies of Gilbert $(17, a, c)$ and others enable us to perceive the similarity of shoreline and 
ordinary stream-channel forms. Consider, in this connection, the subaqueous strip varying, according to the depth of the water, from a mere ribbon to a band several miles in width, and "curving sympathetically" with the shoreline. The main activities are the waves, tides, and resultant currents. On one side the heavy wind limits the seaward extension, while on the other the shoreline acts as a wall to the (shore) stream. The action of this current is to form a bridge alongshore over which to transport material. The heaviest floods (storms) can utilise low flat grades as bridges which succeeding smaller floods (or gales) find too flat, and which straightway they proceed to aggrade. Again, the heaviest "gale of the generation or century" can work havoc on the cliffs by transport of heavy boulders. With the recession of the great gale these are dropped, and succeeding heavy but weaker gales can merely override, but not move, these boulders. Thus the deadly weapon to the cliffs in the hand of the great gale has become a veritable buttress to the cliffs during the period of lesser winds

\section{Significance.}

It may seem a simple matter to accept Gilbert's principle, namely, that the great flood accomplishes the main portion of stream-work, nevertheless it is almost safe to state that its proper understanding would lead to results almost, if not quite, as remarkable as those which have followed on the proper apprehension of other fundamental geological conceptions. For the light thrown thus on glacial methods is almost incredible at first glance, while the value of ice-action studies in any discussion as to methods of peneplanation is, in turn, strikingly apparent. And for this purpose, when discussing stream-channel grades, it would appear advisable to consider the channel-contour rather than the surface of the waterbody contained therein.

Prof. Davis has by letter pointed out to the writer that the term "grade" as applied to streams should have reference more correctly to their surface-levels; for the purposes of this note, however, interest centres around the channel-contours them- 
selves. In youthful dissection one finds the greatest discordances in these channel rock-slopes; while in extreme old age the grades are almost perfectly harmonious: in other words, in areas of little or no relief gravitative thrust is reduced to a minimum.

Believing firmly in Gilbert's principle, the writer has ventured to announce the existence of certain land-contours the world over on the assumption of such principle. Contours in glaciated regions have been specially selected for consideration because of the various conflicting views entertained as to their origin.

\section{A. Glacial phenomena.}

(a) Fiord regions.-Alaska, New Zealand, Norway, Patagonia.

The following deductions are based partly on the belief that in these regions fierce but short-lived glacial floods acted along profound stream-formed cañons, and, in part, also, on the belief that glacial action is analogous to that of water streams. This conclusion is based on a comparison of glaciated and non-glaciated western New Zealand. The contours expected in glaciated areas on such analogy would be much as follows:-

i. Cañons of profound depth with comparatively wide and flat floors.

ii. Rectilinear walls in part. Compare Fig.3 illustrating roadside gutter-development during floods whereby deep straight trenches are excavated.

iii. Floors of cañons interrupted frequently by terraces possessing, approximately, amphitheatrically shaped heads. Compare Figs. 4 and 7.

iv. Cañons terminating frequently in magnificent cirques. See Figs. 2 and 3.

v. Cirques or, at times, precipices under smoothed cols.

vi. Basins at feet of cirques with reversed grades lower downstream. Compare with Fig.2.

vii. Cañon floor-grades interrupted by basins at various points:

(a) At marked cañon-convergences, especially where the main valley is but slightly larger in cross-sectional area than either of ts feeders. 
(b) Cañon-narrows between exceptionally high and resistant walls.

(c) Areas of heavy thrust joining points of marked cañon convergence, or several points of maximum gravitative thrust.
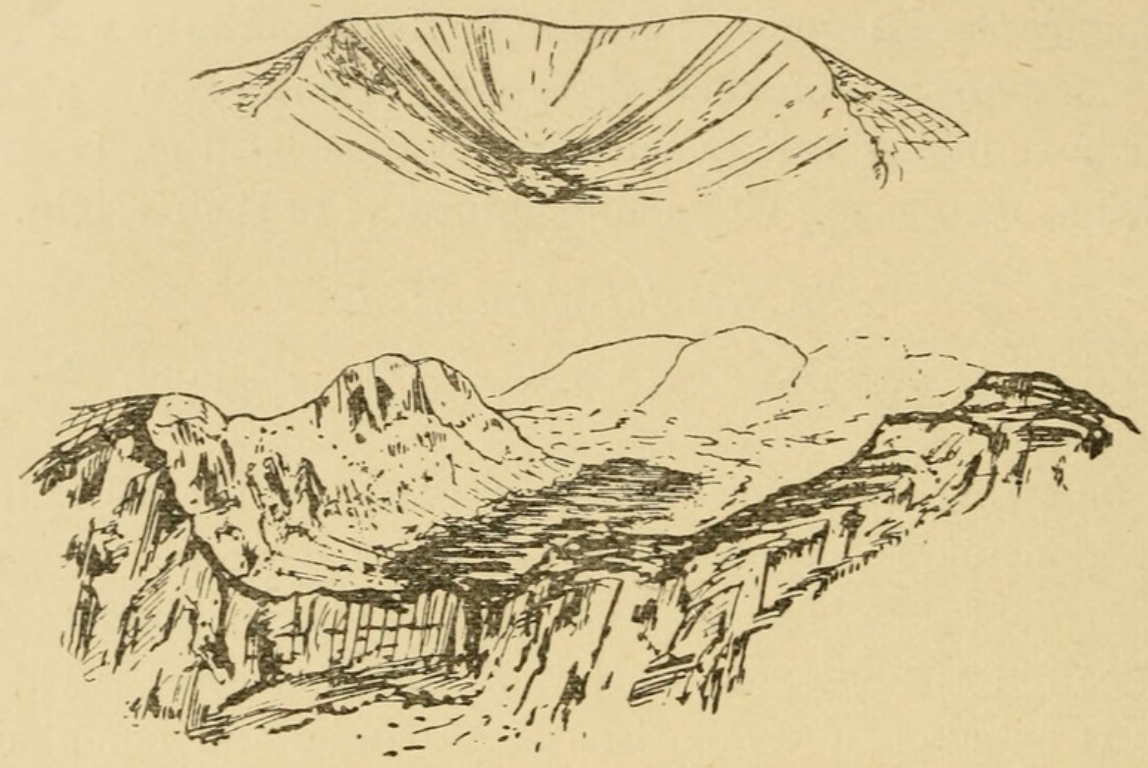

Fig.8.-Cirque-formations. Compare with figs. 1, 2, and 3.

To this case the writer would direct special attention, as thereby main fiord-excavation is probably explicable. And, at a glance, it will be seen that this is but a logical conclusion from a study of an example as depicted in Fig 6 .

The trench depicted in Fig. 6 was formed by the establishment of a point of heavy gravitative thrust downstream. This formed a marked discordance of grade; and the trench resulted from the recession of the initial waterfall. The higher the waterfall and the greater the water volume, the greater the gravitative thrust, that is, the deeper the basin excavated.

Now in a preglacial cañon we have, say, a marked cañonconvergence. A local basin is thus formed by the great iceflood. Upstream another marked convergence occurs, causing a heavy down-cañon thrust. In seeking to harmonise the grade broken by the downstream ice-convergence, the ice-floods of the feeding cañons cause the basin-head to retreat upstream as far as 
the marked upper cañon-convergences. Above these points basin-formation might progress but slowly.

Fiord-, and associated cañon-, basins should be carefully studied with this idea in view. Our only hope lies in studying these analogies, for we have ascertained, both by direct observation and the mechanics of flowing water, that the drought-stream is unable to utilise the flood-stream grade as a working slope: we cannot hope then, in the near future, to witness another ice-flood.

viii. Cañon convergences characterised by absence of morainic débris.

ix. Great deposition of débris below and near the basin-mouths. If the latest flood were enormous, so much freer from débris would the basin be; if a succession of smaller floods should follow, the tendency would be to fill the basin. The more nearly comparable these later floods should be, in point of size, to the large flood producing the basin, the farther down the basin would the débris be forced, leaving the head free and deep. Absolute incompetency to transport would result in delta-forming at the basin-head-in a word, the gravitative thrust would be zero below the local base-level. Compare in this connection Figs. 1 and 2.

$x$. Hanging valleys associated with fiord-basins. If the fiord basin result from ice-thrusts along converging cañons arranged symmetrically to the axis of the main cañon, then the hanging valleys may occur developed equally well along either side of the cañon; if the converging cañon axes be unsymmetrically disposed with respect to that of the main cañon, then along that side of the fiord or cañon facing the resultant ice-thrust one should expect marked undercutting of walls, with development of correspondingly grand hanging valley examples. Hanging valleys may also be formed by the processes described in ix.

xi. A marked inactivity of glacial-action at cañon-divergence (ice-diffluences).

xii. The glaciers succeeding to a period of intense glacial activity would confine their work to aggradation. The glaciers, therefore, which now occupy fiord-basins will be stagnant, over- 
riding the old flood-moraines: in a word, by analogy with ordinary stream-action, they will be found hopelessly incompetent to effect corrasion of their beds.

Thus is deduced a most significant truth that, while presentday glaciers may certainly be studied to great advantage with a view to ascertaining methods of ice-motion on slopes, the work of the recent ice age glaciers cannot be appreciated by such study alone. On the contrary, unless one has a firm grasp of Gilbert's principle, the study of present-day glaciers would actually tend to cause disbelief in the competency of any ice-mass to efficiently corrade its channel. Experiments should be conducted in small stream-formed cañons by forcing strong icestreams along the same for a considerable period. The removal of the ice should then reveal contours such as those just described.

Application.-1. New Zealand: Milford Sound. The convergence of Harrison Cove cañon with the main valley occurs near the Sound-mouth. Several miles higher up is the marked convergence of the Arthur and Cleddau cañons. Probably a basin was formed by the gravitative thrust at Harrison Cove mouth. This basin-excavation was continued upstream by the heavy ice-rush resulting from the marked convergence of the Arthur and Cleddau glaciers. This trough, in the line of fiercest thrust, is, as we should expect, free from morainic material : in fact, the trough itself demonstrates corrasion as opposed to aggradation. The marked shallowing of the main Sound outlet, as revealed by hydrographic surveys, indicates either "dumping" of material here or a slackening off, during the ice-flood, of rockcorrading power. Deltas now occupy the lower portions of the Cleddau and Arthur Rivers. These represent the action of insignificant postglacial water-streams. The resultant set of the former monstrous glaciers of the Arthur and Cleddau cañons was, approximately, to the north-west; therefore the northern wall of Milford should have been specially selected for attack. Undercutting forces would here be at a maximum, and hanging valleys would be correspondingly well "hung up": this is the actual state of affairs at Milford. 
Examples almost equally as striking as those of Milford are to be found in Smith's Sound and Hall's Arm. Preservation Inlet,

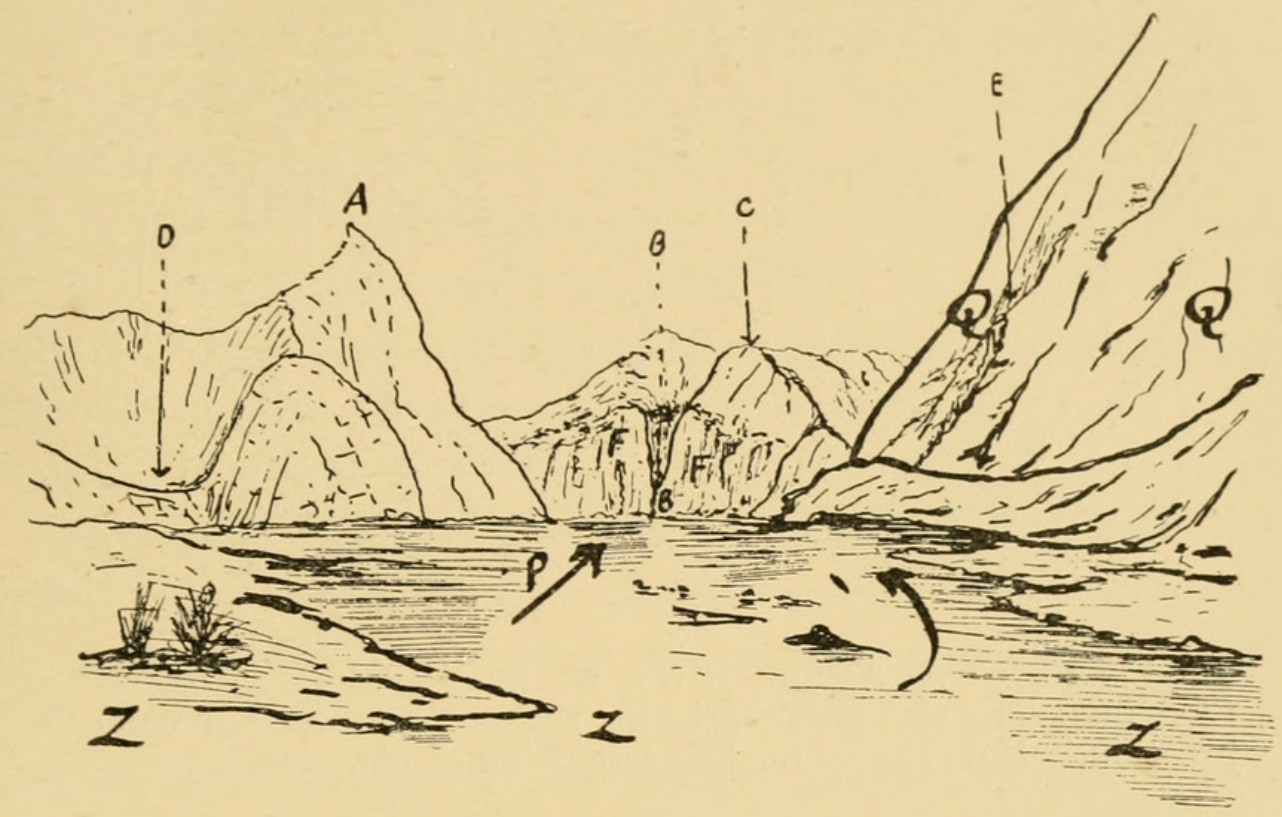

Fig. 9.-General view of Milford Sound from convergence of Cleddau and Arthur cañons.

The major thrust $(\mathrm{P})$ has been directed against the right hand (northern) wall, as shown by marvellously undercut walls, FF and QQ.

A, Mitre Rock; 5,600 feet.

B, Sterling Falls (Hanging Valley); 504 feet.

C, The Lion Rock: 4,300 feet.

D, Sinbad Valley; 5,000 feet deep.

E, The lip of Bowen Falls; 550 feet (caused by enormous undercutting of wall QQ).

FF, Straight wall; 2,500 feet high. Sound 1,500 feet deep under points FFB.

The Sound appears to have commenced by baisining near B, and then carried backwards to ZZZ by recession of ice-fall and marked cañon-convergences.

(Pl.xlv.) on the other hand, exhibits cañon-divergence rather than convergence. Here, then, one would naturally look for islets as evidencing much reduced power of scouring. 
2. N or w a y- - From photographs of Norwegian fiord-scenery one would expect to find a close association of dense rocks, straight

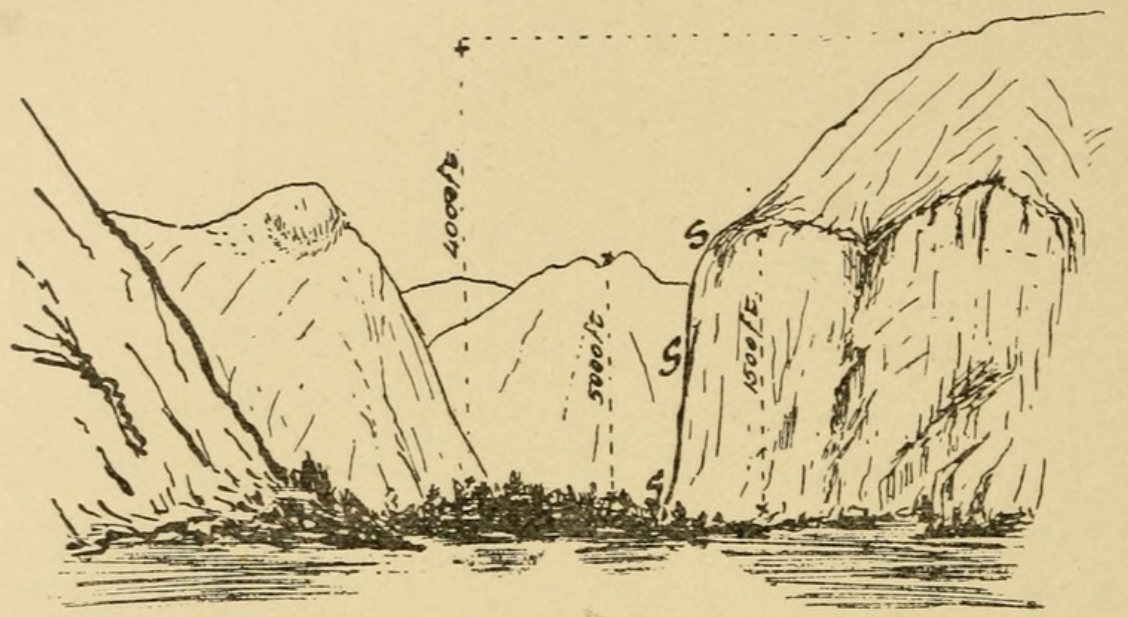

Fig. 10. - The Arthur River at its junction with the Cleddau. The wall SSS marks the actual former glacial flood junction. Note the marked undercutting of cañon walls.

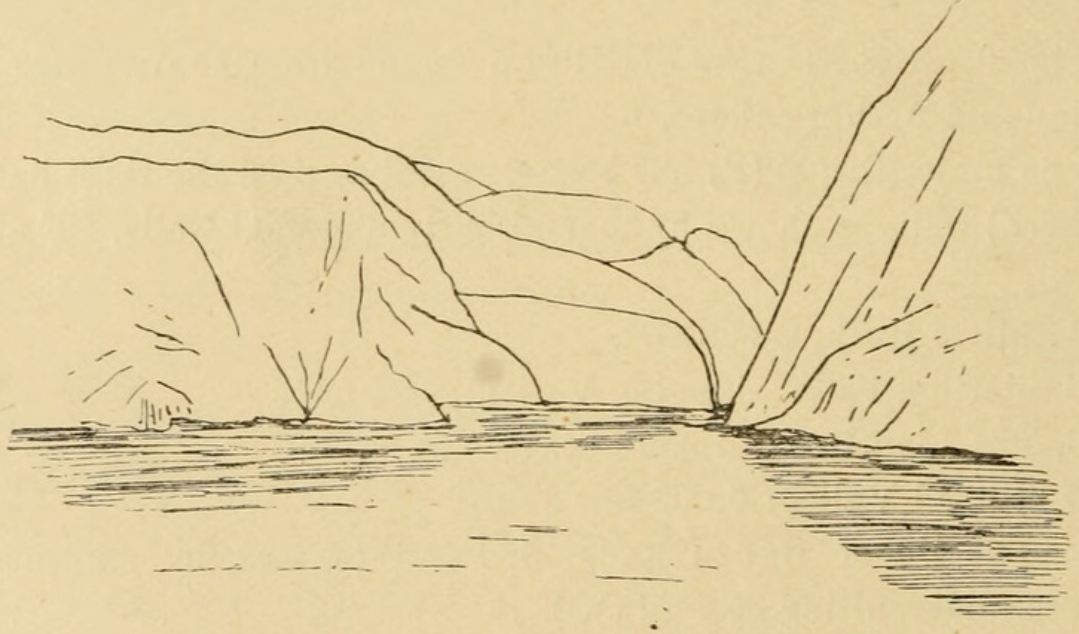

Fig.11.-Sketch of Dusky Sound contours, New Zealand. Note the truncated spurs.

walls, marked cañon-convergence, and development of hanging valleys in the fiords of profound depth, such as the Sogne example is reputed to be. One should look for the long "deeps" to " join hands," as it were, from point to point of marked cañonconvergence. Each great convergence, or sudden narrowing, produced a basin which was continued backwards until it merged 
into that higher up stream. We should thus even look for irregularities of depth from point to point in individual basins (fiords), especially at convergences and narrows.

All broads and divergences, as opposed to cañon-narrows, might be expected to hold less profound fiord-basins; in fact, one would even expect to find islets amid such surroundings.

3. A la s k a.-The remarks made concerning New Zealand and Norway would also apply equally well in this locality. The Muir and Melaspina basins are, doubtless, associated either with marked cañon-convergences, by cañon-narrowing lower down stream, or other points indicative of heavy gravitative thrust.

These brief notes may serve to indicate the writer's general opinion concerning fiord-basins. Of course it is very possible that the glacial floods were not equally persistent in all fiord lands. Each district must be considered separately. Thus, suppose that a severe, or a record, ice-flood marked the last visitation in New Zealand, while a comparatively weak flood marked the Northern Fiord Ice Period. Then, in New Zealand, one would expect clean troughs (fiord-basins), while in the north he would expect heavy morainic deposits in the lower ends of the basins.

Compare figs. 1 and 2.

(b) European Alps, Californian Sierras, the New Zealand Alps, and similar geographic regions.

1. $\mathrm{N}$ ew $\mathrm{Z}$ e a l a nd. - Similar topographic contours might be expected in these localities to those obtaining in the fiord-regions; the main difference being that the fiordcontours are referred to main baselevel, while those of the Sierras and Alps are referable to higher temporary baselevels. Thus, Lakes Wakatipu, Wanaka, Te Anau, Hawea, and Manawapouri in New Zealand, have contours almost identical with those of the fiords on the opposite side of the range; the lake-surfaces, however, are generally 1,000 feet above sea-level. Hanging valleys and lake-depths are, apparently, not so pronounced as in fiords. This is doubtless connected with the heavy precipitation to be found in fiord-regions. In New 
Zealand, while the fiord-region gets from 150 to 250 inches of moisture per annum, Lakes Wakatipu and Te Anau probably do not exceed 60 inches. A comparable precipitation probably obtained in the Ice Age, since no earth-movements of note appear to have taken place here in postglacial time.

2. Sie r r a s.-A magnificent set of photographs illustrating geographic contours in the Canadian Rockies has been presented to the writer by A. O. Wheeler, of Calgary; and these shew forms identical with New Zealand Alpine types.

It is more than possible that the grand cañon-contours of the Sierras are associated with marked cañon-convergences, or that basins (lakes) have been formed by corrasion at marked convergences, and lengthened by gravitative thrust of the upstream glacier in its attempts to harmonise the cañon-grades. Hangingvalleys, sheer precipices and spurs shrivelled up to the main cañon-wall should be studied in connection with known direction of resultant thrusts from cañon-convergences. Lake Chelan appears to be a remarkable study in structural strength, allowing of profound preglacial narrows; of cañon-convergences with trough (lake) development by reason of headward retreat of heavy icefalls initiated by some downstream cañon-convergence. Mono Lake region also appears to be a study in resistance or differential strength.

Cirques, also, probably arise in the main from the plunging action of floods, as exemplified by ordinary stream-action. Associated cols, when present, should always be examined in this connection to discover the catchment area really belonging to a cañon during the Glacial Period. Willard D. Johnson, however, in a brilliant note (19), suggests that cirque-corrasion is progressing now along lines "curving sympathetically" with the bergschrund. All such localities should be studied in connection with the provisions of the Ice-Flood Hypothesis.

One point which must not be lost sight of in this glacial study is, that intense ice-action, as water-action, is extremely localised. More misconceptions appear to have arisen from an oversight of this fact than any other. With streams seeking the baselevel, 
the points of heavy gravitative thrust are the major discordances of channel-grade, howsoever initiated. Now, from considerations of earth-relief these are seen to be common only in Alpine or similar regions where torrent-tracks and marked cañonconvergences abound. Glacial contours should therefore be expected to reveal their magnificence in such regions, and be reduced almost to vanishing point when traversing regions of gentle relief.

We shall see how applicable all this is when discussing corrasion by an ice-sheet.

3. European Alps.-As with the New Zealand Alps, the Californian Sierras, and the Canadian Rockies, so we should expect certain land-forms in the European Alps. The descriptions of Brigham (2), Davis (9a), Garwood (14), Penck (22) and others, have enriched our knowledge of this region. Each of such forms should be studied in connection with geologic structure, preglacial cañon-convergences, and cañon-broads or narrows. In studying glacial convergence one must not be altogether guided by the disposition of the lower cañon-base; he must consider the cañon as a whole, otherwise he will be led into serious errors.

For the European Alps, Garwood's excellent photographs reveal forms precisely similar to those expected by the writer on the assumption of the ice-flood hypothesis.

\section{c. Areas traversed by a Continental Ice-Sheet.}

Imagine an ice-sheet covering all or almost the whole of a large land-area. It is immaterial for our purpose whether the sheet forms at one or more centres. In the case of several centres the meeting-points are those, apparently, of reduced energy so far as external glacial work is concerned. The problem then resolves itself into one of a broad knowledge of preglacial topography.

i. Suppose the ice-sheet to descend an area of excessively rugged topography. The forms described under headings $\mathrm{A}$ and $\mathrm{B}$ should now be looked for. The less rugged the land-masses, 
the less their vertical relief, and the wider the valleys the less marked the canon-convergences (as concerns heavy ice-thrusting), and hence the less marked the resultant ice-thrusts.

Exoamples.-Possibly Patagonia and certain portions of Alaska. The Highlands of Scotland, and the English Lake District afford instructive examples of more moderate action.

\section{ii. The ice-sheet traversing areas of mature to senile topography.}

The ice-sheet now, as it covers the land-forms, has general directions of motion from its centres, but along those valleys only whose main axes coincide with these directions will the glaciallydeveloped contours be similar and similarly situated. Each range and valley crossed by the ice-cap will now react on the passing mass, just as boulders and other obstacles in streamchannels react on the passing stream. And, here again, the writer would insist on the careful examination of the small, and easily understood stream-forms, so as to allow of correct reasoning thence to the majestic ice-flood contours. Local eddies are produced which, in each case, determine the contours at those spots. The general direction of the ice-motion will, of course, be unaltered, but local contours will be altogether inexplicable, unless one has a clear understanding of the action of water-or ice-eddies set up by the channel-obstructions.

Thus, imagine an ice-cap to be moving southwards from a landmass, as shown at $\mathrm{A}$ in accompanying sketch, and crossing two valleys $B$ and $C$, separated by a high ridge $P P$, and partly connected by a low col QQ. The valley $B$ faces the east, and the valley $\mathrm{CGCH}$ the west. As the ice-cap moved over the high separating ridge the general motion of the mass was towards the south, but a lower ice-flow was set up easterly along the valley $B$. The col at $Q Q$ caused another local ice-eddy which, in turn, swept westerly down the upper portion of the valley CGCH. A cirque and basin may thus be formed at the foot of the col QQ, with alignment of valley-wall masses as in direction indicated by the arrows FF. All these forms are inexplicable on the assumption of ice-cutting from north to south only. 
A very similar case was actually observed last January while visiting Mount Kosciusko in company with Professor T. W. E. David, who in (7), for the first time, had satisfactorily and clearly
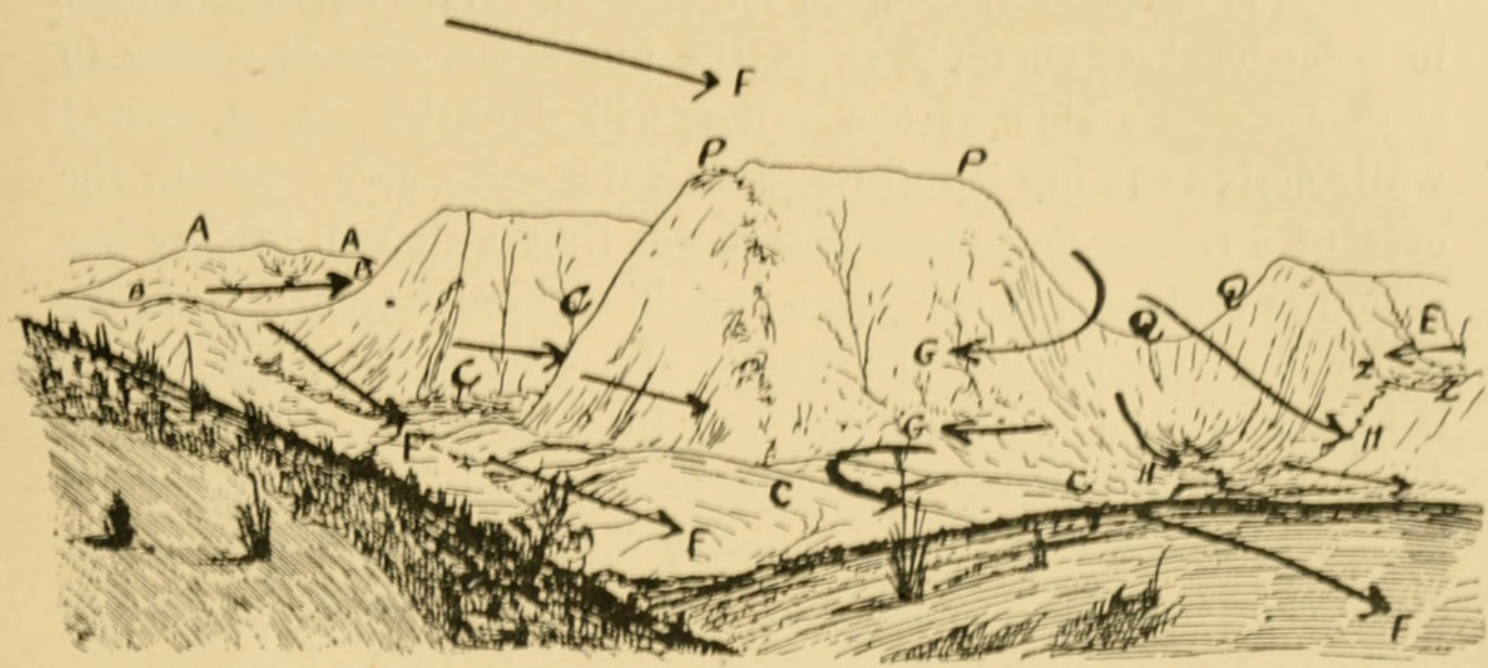

Fig, 12.-Ideal sketch illustrating action of ice-sheet at Kosciusko. AA, Kosciusko Range; BB, Snowy River Valley; CC, drainage of Spencer Creek; FFF, general direction of ice-motion; $\mathrm{GG}, \mathrm{HH}$, ice eddies-caused by col QQ and mountain PP; QQ, hanging valley caused by eddy $\mathrm{HH}$. The arrows indicate the motion of the ice at various points, as suggested by the topography.

stated the existence of a magnificent Pleistocene glaciation for this area.

We insist again then, that first and last, the topography must not be lost sight of. Without the aid of figures it would be difficut to discuss the case in detail; several ideal examples may, however, be considered briefly.

(i.) Cañons opening on to Flats or broad Valleys and facing the general direction of the Ice-Flow.

The general land-surface would be but very slightly eroded, since there are few marked descents or convergences to increase velocity, and hence produce heavy local ice-thrusts. The basal ice, however, upon reaching the cañons would suffer convergence in being forced to flow up these narrow trenches while sealing. the range. Hence added velocity with strong corrasion of these cañon bases.

Ex a m ples.-Finger Lakes of New York (?). 
(ii.) Wide valleys protocted by fairly high but flaring sides.

The general shape and arrangement of the valley will determine which side is specially selected for attack. Here again one must look for local ice-currents as in the analogous case of eddies in streams. One side of the valley will doubtless be protected while active cutting is in progress on the other side. As in the case of streams, one must not forget that although intense iceaction is probable, it can have but local application. And the wider the valleys, and the flatter the grades, all other things being equal, the more limited the intense action. This arises from the significance of the term base-level. Every water-pond is a potential waterfall, its capacity for work depending on the amount of head it may possess. Wide sluggish streams forced into narrows, or into any position where gravity has freer action, will accomplish wonders. The lower Amazon turned into the Yosemite cañon would accomplish such work as to amaze even experienced engineers. The tourist finds difficulty in recognising the smooth, and almost greasily-surfaced above-the-fall water as the same with that which pursues its mad career along the torrent-track under the falls. Yet the sluggish upper mass and and the lower "river gone mad, with boulders and mud for water," are one and the same. Niagara and Zambesi are the grand examples. It is but a simple application of the truth that, for streams, the power of transportation varies as the sixth power of the velocity. And here we perceive the reason for limited evidence only of intense former ice-cutting in areas of low relief. The points of intense action are those of great gravitative thrust, such as great fall or marked convergence. In fiord and alpine regions these conditions abound, hence magnificent contours; but as one rarely finds a Niagara on the low country, so one but rarely finds signs of magnificent rock-basining by ice over country of gentle relief.

Therefore the study of such glacial contours should properly commence in alpine regions, and thence be carried back among areas of less marked gravitative thrust. 
(iii.) Recession of great ice-flood, and subsequent smaller-flood action.

The ground-moraines of the great ice-flood are too massive to be moved bodily by the shrunken glacier. The moraines are overriden simply and not used as weapons of corrasion; channels are excavated in these deposits; their surfaces are rounded and aggradation of pronounced surface-irregularities is characteristic. In this way the writer would account for many drumlin-mass surfaces. Doubtless the great drumlin-masses were due to the action of a great ice-flood; their present appearance is due to the mere rounding of same by smaller ice-flood visitation. Other conditions remaining unaltered, one must remember that the evidence of numerous small advances of an ice-sheet succeeding to a much greater glacial visitation admits of ready perception, whereas, on the flood hypothesis, the evidence of such weaker ice-mass visitations would be practically destroyed by a later severe glacial attack. Therefore, on the assumption of a period of stable equilibrium for a certain land-mass, one would expect only with great difficulty to trace the history of minor glaciation preceding a great ice-flood.

A knowledge of this simple fact may, again, explain many previous glacial difficulties.

\section{B. Ordinary Streams.}

All other geographic conditions being equal, land-areas dependent for their water-supply on terrific storms of infrequent occurrence should be reduced to base-level more quickly than one of much heavier precipitation, but not subject to violent storms.

Firstly, since the vegetation begotten of frequent rainfalls is a great check on corrasive activities.

Secondly, because the marked absence of great storms or "cloudbursts" in the moist region affords little opportunity for greatly increased work.

In the arid region the association of unprotected talus and "cloudbursts" is productive of marvellous corrasive results.

Example.-The graded condition of Western New South Wales streams as compared with the immaturity of streams in 
the much moister eastern division of the State, the streams being of the same age.

\section{Shoreline Studies.}

The ordinary heavy gale is unable to use the weapons of the great storm of the century. Beneath the cliffs lie these great storm-relics, unaffected by the ordinary storm-wave; in fact they actually protect the cliff against the buffets of these lesser stormwaves. Thus, to the unobservant, the strength of the grand visitation is itself an evidence of flood-wave incompetency. Let, however, the requisite velocity be again forthcoming and the inertia of the flood-débris is once more overcome; the giant recommences work; the rock-shelf undergoes corrasion; and great sand-barriers are thrown up in spots removed from cutting curves. But with the departure of the great gale its working grade becomes too flat for smaller subsequent storm-currents to work along, and aggradation of these flood-contours ensues.

\section{The Pereplain.}

The peneplain is formed, approximately, at sea-level. However great the initial vertical relief, the streams make an early attempt to reach baselevel. In the cañon stage, many basins are formed actually below baselevel; with progressive reduction of land-surface-all other conditions remaining constant-the gravitative stream-thrusts become less. In extreme old age the streams have no action below baselevel, and the peneplain consists of a central system of very low undulating surfaces associated with wide plains showing a very gentle fall to main baselevel.

\section{SuMMARY.}

An examination of the flood-channel contours of ordinary streams reveals many interesting and significant features. Trenches with straight sides and terminating headward in basinshaped contours are of common occurrence; the floors also of tributary streams are slightly hung above the base of the main stream, while the absence of spurs and alignment of banks or miniature bordering cliffs is pronounced. Basins also with 
reversed grades downstream, but unassociated with troughs, are features of flood-channels.

Alike in the roadside gutter, the incipient cañon, the brooklet, the brook, the small and the mighty river, these forms occur over and over again. In each type of channel the dimensions of these peculiar contours are intimately related to those of the accompanying stream when in flood. Furthermore, such shapes, by direct observation, are known to express the work of the mightiest floods only which obtain in the various localities. And again the situations of such forms are exactly those which might have been easily predicted from considerations of gravitative thrust; that is, they occur :-

i. At points of marked convergence.

ii. Along lines working upstream from points of marked convergence.

iii. Along lines connecting points of marked convergence.

iv. Above points which, by reason of superior hardness or softness, have allowed of pronounced differential vertical corrasion.

These "facts of form" suggest that along a channel-floor of definite slope, a flood, or rather a flood-series, descended. The gravitative thrusts of the floods found partial, but not complete, expression in undermining of the channel-sides and in transportation of débris along the base. Relief, however, was in great measure afforded by vertical cutting; and this action ceased only when the vertical component of the gravitative thrust had been expended. A heavy flood-series expressed its maximum vertical thrusts as a succession of basins and troughs along the streamchannels, while subsequent lesser-flood action was incompetent to reduce the grades so formed, and was directed rather to aggradation of channel-base irregularities.

Again, forms almost identical with those just enumerated may be seen along shorelines or the cañons and valleys but recently vacated by the huge glaciers of the "Ice Age." The grandest contours of fiord cliffs and basins are not only similarly shaped but similarly situated to those formed by ordinary stream-floods. 
The one marked difference is the wonderful disparity in size existing between water- and ice-formed contours.

Now in roadside gutters and other small stream-examples these peculiar contours are known, by direct observation, to originate in flood-water thrusts: in the cases of the great rivervalley, the shoreline and the glacial cañon, we infer a similarity of origin for their similarly situated contours. And the reasoning is equally sound when applied to the case of the larger forms, for in addition to the similarity of contour-shape and location for both large and small examples; in addition also to the fact that floods occur in the cases of seawaves and ice, and that the peculiar shoreline and fiord contours under consideration do not rise above the highest floodmarks, the dimensions of the forms, in all instances, possess the most intimate relations with those of the heaviest floods. Thus the basins of roadside gutters rarely exceed a few feet in depth, while those of fiords and lakes in regions of former intense glaciation, besides being similarly situated to those of roadside gutters, may be thousands of feet in depth and many miles in length. Apparently, then the deduction is legitimate that all the forms have a similarity of origin, namely that of flood-stream action.

The apprehension of this truth is of the utmost significance. For since direct observations have shown that the striking irregularities of ordinary stream-developed channel-contours result from severe flood-action, and that lesser flood-action is confined, in the main, to working over the storm débris with aggradation of the larger channel-base irregularities, then a similar condition of affairs must also obtain along Amazonian or Mississippian channels, shorelines, and regions of former intense glaciation.

i. Shorelines.-Since, for waves of translation and for currents, power of transportation increases so amazingly with but moderate increase in velocity, the heavier material moved by the "great storm of the century" cannot be handled by succeeding gales of less velocity. Only with the visit of an equally strong wind can this heavy material be forced into activity, so that cliffs and rock- 
platforms may be still further reduced. Until such time the weapons of the "record" gale, by their very mass, act as a decided protection to the shoreline, and energy is confined to rearrangement of smaller-storm débris and smoothing over of major irregularities of shoreline contour.

Similar reasoning applies to the action of the great storm in handling vast areas of sand, thus modifying the coastal profile. In this case it is the mass of sand capable of being moved in a given time which enables work thus to be done that is not wholly destroyed by successive years of interstorm activity.

ii. Glaciation.-The Glacial Period marked an ice-flood or a series of ice-floods, during which huge basins, spurless walls, terraced floors, hanging-valleys and cirques were formed. The disappearance of the Ice Age would signify a glacial drought. By analogy with ordinary stream-action, ice-stagnation would characterise such reduced glaciers. Along the old flood-worn channels the gravitative thrusts of these shrunken glaciers would be expended before the deeper portions (basins) of the channel bases were reached. These drought ice-streams then would be competent only to rearrange the old flcod débris, and to round over the moraines. Hence arise :-

(a) Stagnating glaciers such as occur in the Muir and Melaspina localities.

(b) Pronounced overriding of moraines by glaciers.

(c) The peculiar appearance of drumlin areas.

(d) The obliteration of smaller ice-flood action by great icefloods, on the assumption of stable equilibrium for the local landmass during such glacial action.

Again, since maximum stream-thrusts are, from gravitative considerations, extremely localised and depend on channelslopes and convergences, so glacial corrasion, as regards deep basin-formation and spur-cutting, is of rare occurrence. A Niagara, a Victoria, a Yosemite, or a Yellowstone waterfall is rare, and determined by some marked channel-grade discordance, whereby great velocity is attainable. So also the flood-glaciation of Yosemite, Alaska, Norway and other regions of similar great 
topographical relief and "torrent tracks" would be marvellous; while in the more mature or even senile topography of the Central and Eastern United States, one would expect such heavy thrusts to be of extremely rare occurrence, and confined to gorges, to valleys facing the advancing ice-sheet, and to similar points at which convergence and, thereby, velocity is emphasised.

Especially important then is the necessity for understanding perfectly the state of dissection attained in preglacial time. Only in this manner may the work of the great local ice-eddies be appreciated.

\section{LITERATURE.}

(1) Andrews, E. C.-(a) The Ice-Flood Hypothesis of the New Zealand Sound Basins. Journal of Geology, Chicago, xiv. 1906, pp. 22-54.

(b) The New Zealand Sound (and Lake) Basins and the Canyons of Eastern Australia in their Bearing on the Theory of the Peneplain. Proc. Linn. S'oc. N.S. Wales, 1906, xxxi. pp. 499-516.

(2) Brigham, A. P.-Glacial Erosion in the Aare Valley. Bull. Geol. Soc. $A m$. ii. 1899, pp. 589-592.

(3) Chamberlin, T. C.—(a) Journ. Geology, ii. 1894, pp. 517-539, 649-667, 768-789.

(b) Op. cit. iii. 1895, pp. 61-70, 198-219, 469-481, 565-583, 668-682, 833-844.

- (c) Op. cit. iii. 1896, pp. 582-593.

(4) Chamberlin and Salisbury- $(a)$-Text-book of Geology, i.

(5) Colver, G. E. - (a) The Erosive Action of Ice. Trans. Wisconsin Acad. Sci. Arts and Letters, x. 1895, pp. 339-366.

(6) Cushing, H. P.-(a) Notes on the Muir Glacier Region, Alaska, and its Geology. American Geologist, viii. 1891, pp. 207-231.

(7) David, T. W. E.-Evidence of the Glaciation in late Cainozoic time at Kosciusko. Keport Aust. Assoc, Adv. Sci., ix. Hobart, 1902, pp. 202 204.

David, T. W. E., Helms, R., and Pitminann, E. F.-Geological Notes on Kosciusko, with Special Reference to Evidences of Glacial Action. Proc. Linn. Soc. N. S. Wales, 1901, xxvi. pp. 26-74.

(9) Davis, W. M. - (a) Glacial Erosion in France, Switzerland and Norway. Proc. Boston Soc. Nat. Hist. xxix. 1900, pp. 273-322.

(b) Glacial Erosion in the Valley of Ticino. Appalaohia ix. 1900, pp. 136-156.

- (c) The Sculpture of Mountains by Glaciers. Scott. Geog. Mag. Jan., Feb., 1906. 
(10) Dotron, C. E. - Tertiary History of the Grand Canyon District. U.S. Geol. Surv. Monographs, ii.

(11) Farrchild, H. Le Roy.-(a) Ice Erosion Theory a Fallacy. Bull. Geol. Soc. Am. xvi. 1905, pp. 13-74, Pls.12-23.

(12) TARR, R. S.-Glacial Erosion in Alaska. Reprint from Popular Science Monthly, lxx., Feb., 1907.

(13) Gannetr, H.-(a) Lake Chelan. Nat. Geog. Mag. ii. pp. 417-428. Quoted from Davis, W. M. (9a), pp. 318-319.

(14) Garwood, E. J.-(a) The Tarns of the Canton Ticino. Quart. Journ. Geol. Soc. lxii. 1906, pp. 165-193, Pls.vii.-xxi.

(15) Garwood, E. J., and Gregory, J. W.-(a) Contributions to the Glacial Geology of Spitzbergen. Quart. Journ. Geol. Soc. liv. 1898, pp. 197225, Pls. xiii.-xix.

(16) Geikie, J.-The Great Ice Age, London. E. Stanford.

(17) Gilbert, G. K.-(a) The Topographic Features of Lake Shores. U.S. Geol. Surv. Fifth Ann. Report, 1883-1884, pp. 77-123.

(b) The Henry Mountains, Reports Geog. Survey of the Rocky Mtn. Region, 187, No. 2.

(c) Lake Bonneville. U.S. Geol. Surv. Monograph i. 1890.

(d) Glaciers. Harriman Alaska Expedition, iii.

(18) Golliver, F. P.-(a) Shoreline Topography. Proc. Am. Acad. Arts Sci. xxxiv, 1899.

(19) Johnson, Willard D.-The Profile of Maturity in Alpine Glacial Erosion. Journ. Geology, xii. 1904, pp. 569-578.

(20) Matthes, Frangois E.-Glacial Sculpture of the Bighorn Mountains, Wyoming. Twenty-first Ann. Rept. U.S. Geol. Survey, Pt.ii. 1899-1900, pp. 169-190.

(21) McGee, W. J.-(a) Quoted from Davis, W. M. (9a), pp. 311-312. (b) Glacial Canyons. Journ. Geology, ii. 1894, pp. 350-364.

(22) Penck, Albrecht. - (a) Glacial Features in the Surface of the Alps. Journ. Geology (reprint) xiii. 1905, pp. 1-19.

(b) Quoted from Davis, W. M. (9a), p. 319.

(23) Powell, J. W.-The Geology of the Uinta Mountains. Geog. and Geol. Survey of the Rocky Mountain Region, No. 1.

(24) Reid, H. F.-(a) Glacier Bay and its Glaciers. Sixteenth Ann. Rept. U.S. Geol. Survey, 1896, pp. 454-458.

(b) The Mechanics of Glaciers. Journ. Geology, iv, 1896, pp.912-928.

(25) Russeld, I. C.-(a) Quaternary History of Mono Valley. Eighth Ann. Rept. U.S.Geol. Survey, Pt. i. 1889, p. 352.

(b) Origin of the Gravel Deposits beneath Muir Glacier, Alaska. American Geologist, ix. 1892, pp. 190-197.

(26) Salisbury, R. D.-Review of Geikie's "Great Ice Age." Journ Geology, ii. 1894, pp. 730-747. 
(27) TARR, R. S.- (a) Hanging Valleys in the Finger Lake Region of Central New York. American Geologist, xxxiii. 1904, pp. 271-291.

(b) Lake Cayuga a Rock Basin. Bull. Geol. Soc. Am. v. 1894, pp. 339-356.

(28) TARr, R. S. and Martin, L.--(a) Glaciers and Glaciation of Yakutat Bay, Alaska. Bull. Amer. Geog. Soc. xxxviii. 1906, pp. 145-167.

(29) Turner, H. W.-The Pleistocene Geology of the South-Central Nevada, with especial Reference to the Origin of Yosemite Valley. Proc. Cal. Acad. Sci. 3rd Series, Geology, i. 1900, pp. 261-321.

(30) Westgate, Lewis G. - The Twin Lakes Glaciated Area, Colorado. Journ. Geology, xiii. 1905, pp. 285-312.

(31) Willcox, Oswin W.-The Viscous versus the Granular Theory of Glacial Motion. Quoted from Review in Geographical Journal, xxix. 1907, pp. 559-560.

\section{EXPLANATION OF PLATES XLIV-XLV. \\ Plate xliv.}

The Junction of the Arthur and Cleddau Rivers, Milford Sound. Note the wonderful undercutting as shown on the cliffs to the right hand of picture.

\section{Plate xlv.}

Preservation Inlet. Glacial diffluences appear to be associated with weak glacial corrasion, as evidenced by islands. Contrast with Plate xliv., in which a marked cañon-convergence is shown. 


\section{$2 \mathrm{BHL}$ Biodiversity Heritage Library}

Andrews, E. C. 1908. "The geographical significance of floods, with especial reference to glacial action." Proceedings of the Linnean Society of New South Wales 32, 795-834. https://doi.org/10.5962/bhl.part.19590.

View This Item Online: https://www.biodiversitylibrary.org/item/30115

DOI: https://doi.org/10.5962/bhl.part.19590

Permalink: https://www.biodiversitylibrary.org/partpdf/19590

\section{Holding Institution}

MBLWHOI Library

\section{Sponsored by}

MBLWHOI Library

\section{Copyright \& Reuse}

Copyright Status: NOT_IN_COPYRIGHT

This document was created from content at the Biodiversity Heritage Library, the world's largest open access digital library for biodiversity literature and archives. Visit BHL at https://www.biodiversitylibrary.org. 